\title{
Heterotrophic Nitrification and Aerobic Denitrification by Four Novel Isolated Bacteria
}

\author{
Xuanzhen $\mathrm{Li}^{1,2}$, Shengfa $\mathrm{Wu}^{1}$, Yangyang Shen ${ }^{1}$, Yongxia Ning ${ }^{3}$, Xiaolin Zhang ${ }^{3}$, \\ Xiaoxue Sun ${ }^{4}$, Bao Zhang ${ }^{5}$, Jinyuan Chen ${ }^{1 *}$ \\ 'College of Biological and Environmental Engineering, Zhejiang University of Technology, 310032 Hangzhou, China \\ ${ }^{2}$ College of Forestry, Henan Agricultural University, 450002 Zhengzhou, China \\ ${ }^{3}$ College of Life Science, Henan Agricultural University, 450002 Zhengzhou, China \\ ${ }^{4}$ College of Resource and Environmental Science, Henan Agricultural University, 450002 Zhengzhou, China \\ ${ }^{5}$ College of Crop Science, Fujian Agriculture and Forestry University, 350002 Fujian, China
}

Received: 26 November 2014

Accepted: 28 January 2015

\begin{abstract}
Heterotrophic nitrifying bacteria are attracting increasing interest due to their advantages in treatment of wastewater with high nitrogen concentration. In this work, four bacterial isolates (WS-1, WS-4, WS-6, and WS-7) with the capability of simultaneous heterotrophic nitrification and aerobic denitrification from soil, sludge, and water by a fast isolation procedure were studied. Isolates WS-1, WS-6, and WS-7 were identified as Pseudomonas sp. and WS-4 as Agrobacterium sp. based on 16S rRNA gene sequence analysis. All four isolates could utilize ammonia, nitrate, and nitrite as sole nitrogen source and the metabolic characteristics were shown to be related with the genus. In addition, Agrobacterium sp. WS-4 accumulated less nitrate than the three Pseudomonas sp. strains with ammonia as the sole nitrogen source. When nitrate or nitrite was the sole nitrogen source, Agrobacterium sp. did not produce ammonia, and it consumed the least nitrogen compared with the three Pseudomonas sp. isolates. Our studies implied that Pseudomonas sp. strains had great potential in treating high nitrogen in wastewater.
\end{abstract}

Keywords: Pseudomonas, Agrobacterium, nitrogen removal, wastewater treatment

\section{Introduction}

Biological nitrogen removal has commonly been used in treatment of wastewater with high nitrogen concentration. Traditionally, nitrogen removal processes were accomplished by nitrifiers and denitrifiers under alternating aerobic and anaerobic conditions. However, the different demands of two sorts of microorganisms in organic matter and oxygen made the treatment process quite complex and tedious. Organic matter was disfavored for nitrifiers while it was indispensable for denitrifiers [1]. Furthermore, the growth of nitrifiers required an aerobic condition that was

*e-mail: cjy1128@zjut.edu.cn harmful to denitrifiers [2]. Due to the different requirements for organic matter and oxygen, the two sorts of microorganisms had to be separated in the wastewater treatment system during the process of wastewater treatment. This extra step increased the operational difficulties. Meanwhile, the slow growth of autotrophic nitrifiers easily caused the wastewater treatment process to be time-consuming and cost-ineffective [2].

Heterotrophic nitrogen removal refers to the simultaneous processes of heterotrophic nitrification and aerobic denitrification by a single strain [3]. The metabolic pathway has been widely accepted as heterotrophic nitrification and simultaneous aerobic denitrification. In 1972, an Arthrobacter sp. strain with the capability of heterotrophic 
nitrification was first isolated from the natural environment [4]. Subsequently, Bacillus sp., Comamonas sp., Diaphorobacter sp., and Pseudomonas stutzeri were identified as strains with heterotrophic abilities $[3,5,6]$.

Heterotrophic nitrification had several advantages over traditional methods. Firstly, the utilization of organic substrates and the tolerance to oxygen of heterotrophic nitrifiers allowed the conduct of simultaneous nitrification and denitrification in the same space and phase. In addition, the process of denitrification could balance $\mathrm{pH}$ in the reactor, avoiding acidification by nitrification. Consequently, heterotrophic nitrogen removal has attracted increasing interest in wastewater treatment [2].

Generally speaking, heterotrophic microbes were isolated from wastewater [2] and membrane bioreactors [3, 7]. In fact, heterotrophic nitrification widely existed in various kinds of environments such as soil and sludge. In this work, four heterotrophic bacteria were isolated and identified from soil and sludge, as well as eutrophic water. Furthermore, their nitrogen removal percentage and transformation profiles were evaluated. Thus it lays the foundation for future wastewater treatment research.

\section{Material and Methods}

\section{Medium and Reagents}

We used the heterotrophic nitrification medium (HNM, $\mathrm{g} / \mathrm{L}):\left(\mathrm{NH}_{4}\right)_{2} \mathrm{SO}_{4}$ 0.66, sodium succinate 4.72, $\mathrm{K}_{2} \mathrm{HPO}_{4}$ $0.50, \mathrm{MgSO}_{4} \cdot 7 \mathrm{H}_{2} \mathrm{O} 0.2, \mathrm{NaCl} 30.00, \mathrm{FeSO}_{4} \cdot 7 \mathrm{H}_{2} \mathrm{O} 0.0025$, and $\mathrm{MnSO}_{4} \cdot 4 \mathrm{H}_{2} \mathrm{O}$ 0.0025. Nitrate medium (NAM) and nitrite medium (NIM) were prepared by replacing $\left(\mathrm{NH}_{4}\right)_{2} \mathrm{SO}_{4}$ in $\mathrm{HNM}$ with $1.05 \mathrm{~g} \mathrm{KNO}_{3}$ and $0.886 \mathrm{~g} \mathrm{KNO}_{2}$, respectively. When prepared for plating, HNM, NAM, and NIM plates contained 1.5\% (w/v) agar. Nessler and Griess reagent were obtained from Sigma-Aldrich. Ferrous sulfate solution was prepared by adding $0.1 \mathrm{~g}$ ferrous sulfate to $100 \mathrm{ml}$ distilled water.

\section{Fast Isolation of Bacteria}

The method to isolate simultaneous heterotrophic nitrifying and aerobic denitrifying bacteria were modified according to to reference [7, 8]. Briefly, $1 \mathrm{~g}$ or $\mathrm{ml}$ soil, sludge, or water was added to sterile water and vortexed for $5 \mathrm{~min}$. After disposition for $5 \mathrm{~min}, 1.0 \mathrm{ml}$ supernatant was added to $100 \mathrm{ml} \mathrm{HNM}$ and incubated on a shaker (180 rpm) at $30^{\circ} \mathrm{C}$ for $24 \mathrm{~h}$. One $\mathrm{ml}$ of the incubated mixture was collected and dripped to white cuvettes with $0.2 \mathrm{ml}$ Nessler reagent. Decolorization of the mixture with Nessler Reagent was regarded as a sign of ammonia removal. Vials showing ammonia removal were selected for further study. Those culture media were plated on HNM medium at proper dilution and incubated $\left(30^{\circ} \mathrm{C}\right)$ for $2 \mathrm{~d}$. The single colonies with lighter color were presumed to have nitrification ability and purified further on NAM and NIM plates. After $2 \mathrm{~d}$ incubation $\left(30^{\circ} \mathrm{C}\right)$, drops of Griess reagent and Ferrous sulfate solution were respectively introduced on individual colonies on NAM and NIM, respectively. The colonies with lighter color were identified as able to denitrify. Both sorts of strains were isolated and stored on slants.

\section{DNA Extraction, PCR Amplification and 16S rRNA Gene Sequence Analysis}

DNA was extracted from bacterial suspensions (1 ml, $\left.\mathrm{OD}_{600}=0.7\right)$ using the EZ-10 Spin Column Genomic DNA Isolation Kit (Sangon, Shanghai). Primers F27 (GTTTGATCCTGGCTCAG) and R1492 (TACGGYTACCTTGTTACGACTT) were used to amplify the 16S rRNA gene by a PCR protocol (PTC200, Bio-Rad, USA). PCRamplified products were purified by the EZ-10 Spin Column PCR Product Purification Kit (Sangon, Shanghai) and 16S rRNA genes were sequenced by Shanghai Invitrogen Biotech Company Ltd. (Shanghai, China). Finally, the 16S rRNA sequence of the isolate was compared with that of other microorganisms by way of BLAST (http://www.ncbi.nlm.nih.gov/BLAST/Blast.cgi).

\section{Shake Flask Experiments}

Strains selected in the previous works were cultivated in HNM, NAM, or NIM for $12 \mathrm{~h}\left(30^{\circ} \mathrm{C}, 120 \mathrm{rpm}\right)$ according to [3]. The treatments without any inoculation served as control and each treatment had three replicates. After centrifuging $\left(4^{\circ} \mathrm{C}, 15 \mathrm{~min}, 5000 \mathrm{~g}\right)$, the pellets were washed three times with sterile water. Then the pellets were suspended in sterilized water to adjust cell optical density $\left(\mathrm{OD}_{600}\right)$ to 0.7 . Then bacterial suspension $(1 \mathrm{ml})$ was placed into conical flasks $(250 \mathrm{ml})$ containing $100 \mathrm{ml}$ $\mathrm{HNM}$ and cultivated at $30^{\circ} \mathrm{C}$ and $120 \mathrm{rpm}$. After $72 \mathrm{~h}$ incubation, the medium was centrifuged $\left(4^{\circ} \mathrm{C}, 15 \mathrm{~min}\right.$, $5000 \mathrm{~g}$ ) to obtain supernatants for the determination of ammonium, hydroxylamine, nitrite, nitrate, and total nitrogen $(\mathrm{TN})$.

\section{Analytical Methods}

Ammonia, nitrite, and nitrate were analyzed according to the standard methods. The ammonia concentration was determined by Nessler's reagent assay at a wavelength of $420 \mathrm{~nm}$. Nitrite was determined by $\mathrm{N}$-(1-naphthyl)ethylene diamine spectrophotometry and nitrate was determined by ultraviolet spectrophothometry under the wavelength of $220 \mathrm{~nm}$ and $275 \mathrm{~nm}$. The amount of total nitrogen was determined by oxidation of potassium persulfate by ultraviolet spectrophothometry. Hydroxylamine was determined according to Frear and Burrell [9]. Bacterial growth was determined by monitoring the optical density at $600 \mathrm{~nm}\left(\mathrm{OD}_{600}\right)$ using a spectrophotometer. Morphological characteristics of the strain were observed by scanning electron microscopy (SEM; JSM-5610LV, Jeol, Japan) after $12 \mathrm{~h}$ incubation. 
Table 1. Ammonia transformation by four strains.

\begin{tabular}{|c|c|c|c|c|c|c|c|c|c|}
\hline \multirow{3}{*}{ Strains } & \multirow{3}{*}{ OD } & \multicolumn{2}{|c|}{$\mathrm{TN}$} & \multicolumn{2}{|c|}{$\mathrm{NH}_{4}^{+}-\mathrm{N}$} & \multicolumn{2}{|c|}{$\mathrm{NO}_{3}^{-}-\mathrm{N}$} & \multicolumn{2}{|c|}{$\mathrm{NO}_{2}^{-}-\mathrm{N}$} \\
\hline & & $\begin{array}{c}\text { Initial } \\
\text { concentration }\end{array}$ & $\begin{array}{l}\text { Removal } \\
\text { percentage }\end{array}$ & $\begin{array}{c}\text { Final } \\
\text { concentration }\end{array}$ & $\begin{array}{l}\text { Removal } \\
\text { percentage }\end{array}$ & $\begin{array}{c}\text { Final } \\
\text { concentration }\end{array}$ & $\begin{array}{l}\text { Productive } \\
\text { percentage }^{\text {a) }}\end{array}$ & $\begin{array}{c}\text { Final } \\
\text { concentration }\end{array}$ & $\begin{array}{l}\text { Productive } \\
\text { percentage }^{\text {a) }}\end{array}$ \\
\hline & & $(\mathrm{mg} / \mathrm{L})$ & $(\%)$ & $(\mathrm{mg} / \mathrm{L})$ & $(\%)$ & $(\mathrm{mg} / \mathrm{L})$ & $(\%)$ & $(\mu \mathrm{g} / \mathrm{L})$ & $(\%)$ \\
\hline WS-1 & 1.2 & 146.00 & $72.19 \pm 0.58$ & $3.78 \pm 0.29$ & $97.41 \pm 0.20$ & $17.90 \pm 1.67$ & $12.26 \pm 1.15$ & $6.9 \pm 0$ & $0.005 \pm 0$ \\
\hline WS-4 & 2.5 & 146.00 & $70.62 \pm 1.20$ & $8.35 \pm 0.40$ & $94.28 \pm 0.30$ & $1.90 \pm 1.28$ & $1.30 \pm 0.87$ & $8.7 \pm 0.2$ & $0.005 \pm 0.0001$ \\
\hline WS-6 & 1.4 & 146.00 & $71.85 \pm 0.33$ & $6.09 \pm 1.27$ & $95.83 \pm 0.90$ & $12.70 \pm 1.05$ & $8.70 \pm 0.71$ & $12.1 \pm 0.9$ & $0.008 \pm 0.0006$ \\
\hline WS-7 & 1.8 & 146.00 & $73.29 \pm 1.10$ & $3.72 \pm 0.07$ & $97.45 \pm 0.05$ & $9.10 \pm 0.41$ & $6.23 \pm 0.28$ & $14.2 \pm 0$ & $0.009 \pm 0$ \\
\hline
\end{tabular}

${ }^{\text {a) }}$ Productive percentage represents the percent of compound accounted for the removed $\mathrm{NO}_{3}^{-}-\mathrm{N}$.

Data are presented as mean \pm S.D., based on three replicates.

Table 2. Nitrate transformation by four strains.

\begin{tabular}{|c|c|c|c|c|c|c|c|c|c|}
\hline \multirow{2}{*}{ Strains } & \multirow{2}{*}{} & \multicolumn{2}{|c|}{$\mathrm{TN}$} & \multicolumn{2}{c|}{$\mathrm{NH}_{4}^{+}-\mathrm{N}$} & \multicolumn{2}{c|}{$\mathrm{NO}_{3}^{-}-\mathrm{N}$} & \multicolumn{2}{c|}{$\mathrm{NO}_{2}^{-}-\mathrm{N}$} \\
\cline { 3 - 10 } & & $\begin{array}{c}\text { Initial } \\
\text { concentration }\end{array}$ & $\begin{array}{c}\text { Removal } \\
\text { percentage }\end{array}$ & $\begin{array}{c}\text { Final } \\
\text { concentration }\end{array}$ & $\begin{array}{c}\text { Productive } \\
\text { percentage })^{\mathrm{a}}\end{array}$ & $\begin{array}{c}\text { Final } \\
\text { concentration }\end{array}$ & $\begin{array}{c}\text { Removal } \\
\text { percentage }\end{array}$ & $\begin{array}{c}\text { Final } \\
\text { concentration }\end{array}$ & $\begin{array}{c}\text { Productive } \\
\text { percentage }{ }^{\mathrm{a}}\end{array}$ \\
\cline { 3 - 11 } & $(\mathrm{mg} / \mathrm{L})$ & $(\%)$ & $(\mathrm{mg} / \mathrm{L})$ & $(\%)$ & $(\mathrm{mg} / \mathrm{L})$ & $(\%)$ & $(\mu \mathrm{L})$ & $(\%)$ \\
\hline WS-1 & 2.3 & 146.00 & $57.77 \pm 0.34$ & $3.73 \pm 0.26$ & $2.55 \pm 0.18$ & $23.42 \pm 1.05$ & $83.96 \pm 0.72$ & $4.02 \pm 0.02$ & $2.75 \pm 0.01$ \\
\hline WS-4 & 1.7 & 146.00 & $25.01 \pm 0.48$ & 0 & 0 & $81.32 \pm 4.30$ & $44.30 \pm 2.95$ & $2.97 \pm 0.02$ & $2.03 \pm 0.01$ \\
\hline WS-6 & 2.3 & 146.00 & $61.69 \pm 0.68$ & $2.68 \pm 0.02$ & $1.84 \pm 0.01$ & $18.36 \pm 0.30$ & $87.42 \pm 0.21$ & $3.88 \pm 0.01$ & $2.66 \pm 0.01$ \\
\hline WS-7 & 2.7 & 146.00 & $54.49 \pm 0.34$ & $1.18 \pm 0.07$ & $0.81 \pm 0.05$ & $23.82 \pm 2.45$ & $83.68 \pm 1.68$ & $3.90 \pm 0.01$ & $2.67 \pm 0.01$ \\
\hline
\end{tabular}

${ }^{\text {a) }}$ Productive percentage represents the percent of compound accounted for the removed $\mathrm{NO}_{3}^{-}-\mathrm{N}$.

Data are presented as mean \pm S.D., based on three replicates.

\section{Results}

\section{Isolation of the Microorganisms}

Different samples including polluted soil, water, and sludge were inoculated in HNM and incubated for $24 \mathrm{~h}$. One $\mathrm{ml}$ medium was collected and mixed with $0.2 \mathrm{ml}$ Nessler reagent. The color of 6 samples became very light compared with the control, indicating that those six samples contained microbes with ammonia removal abilities. The Griess reagent and Ferrous sulfate experiments further indicated the presence of these organism colonies on the plate. These were characterized as potential heterotrophic nitrifying bacteria. Four strains were ultimately selected as aerobic nitrification microbes, and were named as WS-1, WS-4, WS-6, and WS-7.

\section{Identification of Isolates}

Gram-staining, electron microscopy, and genotypic analysis were carried out to identify the isolates. Staining showed that all four strains were Gram-negative. Electron microscopy showed that all WS-1, WS-4, WS-6, and WS-7 were rod-shaped and their sizes were (0.2-0.3) $\mu \mathrm{m} \times(0.8-1.5) \mu \mathrm{m},(0.8-1.2) \mu \mathrm{m} \times(1.5-2.0), \quad(0.2-0.6)$ $\mu \mathrm{m} \times(0.8-1.2) \mu \mathrm{m}$, and $(0.3-0.8) \mu \mathrm{m} \times(1.0-1.4) \mu \mathrm{m}$, respectively.

The nucleotide sequences of their 16S rRNA genes alignment revealed that WS-1, WS-6, and WS-7 were members of the genus Pseudomonas sp., while WS-4 was a member of the genus Agrobacterium sp. (Fig. 1).

\section{Ammonia Transformation by the Isolates}

We evaluated the efficiency of heterotrophic nitrification by four strains with ammonia as the sole nitrogen and sodium succinate as the organic carbon source (Table 1). After $48 \mathrm{~h}$ incubation, more than $70 \%$ of total nitrogen was removed by all four strains, and the maximal nitrogen removal percentage was obtained by WS-7, which was up to $73.29 \%$. All these stains removed more than $90 \%$ of ammonia, and the maximal nitrogen removal percentage was also obtained by WS-7, which was up to $97.45 \%$. Nitrate and nitrite but not hydroxylamine were detected in the culture. WS-1 produced the most $\mathrm{NO}_{3}^{-}-\mathrm{N}(17.90 \mathrm{mg} / \mathrm{L})$, which occupied $12.26 \%$ of initial $\mathrm{NH}_{4}^{+}-\mathrm{N}$. Concentration of nitrate in culture of WS4 was minimal and only occupied $1.3 \%$ of initial $\mathrm{NH}_{4}^{+}-\mathrm{N}$. The accumulation of nitrite by four strains was only detected on the level of $\mu \mathrm{g} / \mathrm{L}$. 

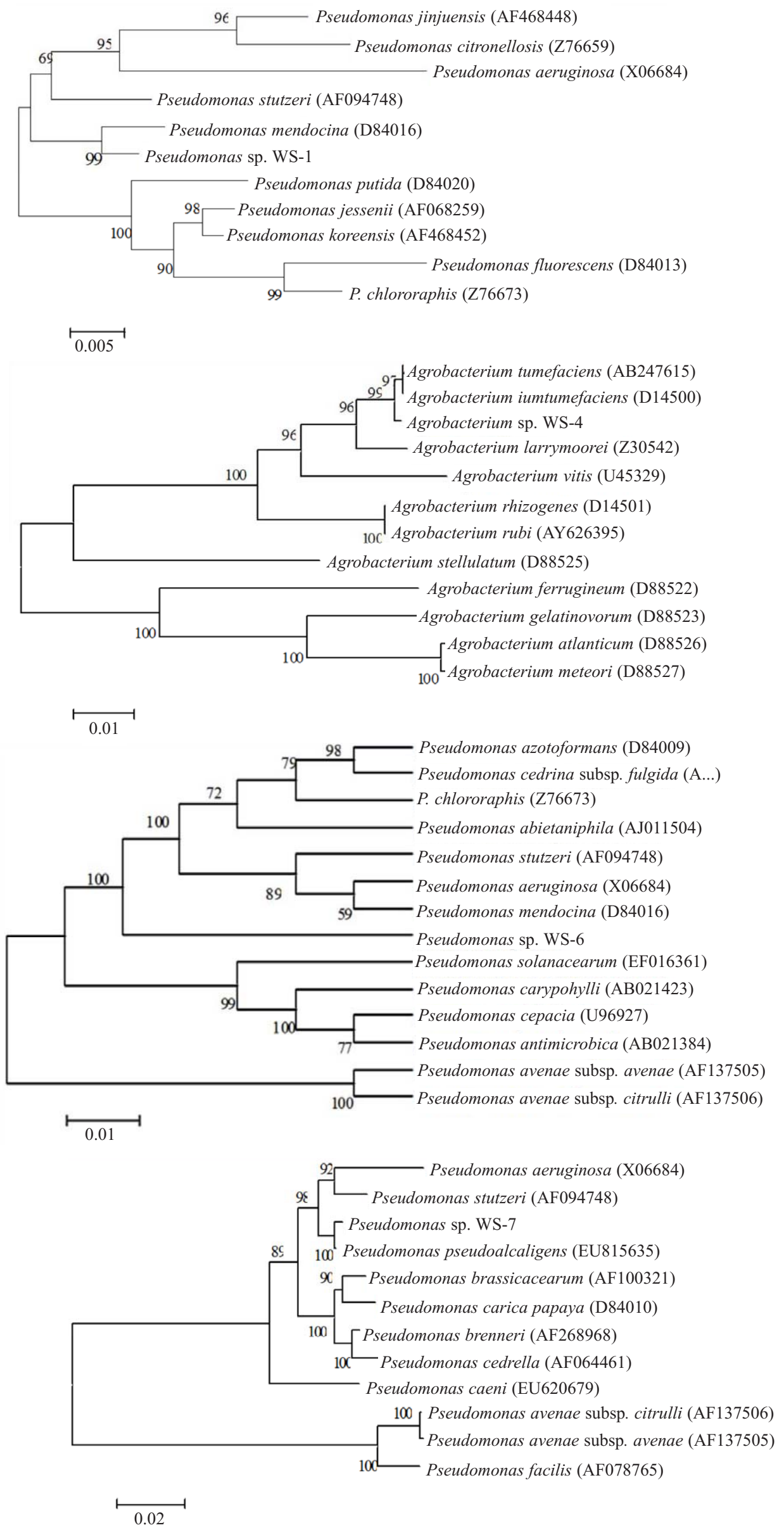

Fig. 1. Phylogenetic tree of strain WS-1, WS-4, WS-6, and WS-7 based on 16S rDNA. 
Table 3. Nitrite transformation by four strains.

\begin{tabular}{|c|c|c|c|c|c|c|c|c|c|}
\hline \multirow{2}{*}{ Strains } & \multirow{2}{*}{ OD } & \multicolumn{2}{|c|}{$\mathrm{TN}$} & \multicolumn{2}{c|}{$\mathrm{NH}_{4}^{+}-\mathrm{N}$} & \multicolumn{2}{c|}{$\mathrm{NO}_{3}^{-}-\mathrm{N}$} & \multicolumn{2}{c|}{$\mathrm{NO}_{2}^{-}-\mathrm{N}$} \\
\cline { 3 - 10 } & & $\begin{array}{c}\text { Initial } \\
\text { concentration }\end{array}$ & $\begin{array}{c}\text { Removal } \\
\text { percentage }\end{array}$ & $\begin{array}{c}\text { Final } \\
\text { concentration }\end{array}$ & $\begin{array}{c}\text { Productive } \\
\text { percentage }\end{array}$ & $\begin{array}{c}\text { Final } \\
\text { concentration }\end{array}$ & $\begin{array}{c}\text { Productive } \\
\text { percentage }{ }^{\mathrm{a})}\end{array}$ & $\begin{array}{c}\text { Final } \\
\text { concentration }\end{array}$ & $\begin{array}{c}\text { Removal } \\
\text { percentage }\end{array}$ \\
\cline { 3 - 11 } & $(\mathrm{mg} / \mathrm{L})$ & $(\%)$ & $(\mathrm{mg} / \mathrm{L})$ & $(\%)$ & $(\mathrm{mg} / \mathrm{L})$ & $(\%)$ & $(\mu \mathrm{g} / \mathrm{L})$ & $(\%)$ \\
\hline WS-1 & 0.8 & 146.00 & $56.54 \pm 1.58$ & $4.73 \pm 0.57$ & $3.24 \pm 0.39$ & $29.07 \pm 1.30$ & $19.91 \pm 0.89$ & $19.73 \pm 0.17$ & $86.49 \pm 0.12$ \\
\hline WS-4 & 0.1 & 146.00 & $4.03 \pm 0.34$ & 0 & 0 & $116.60 \pm 0.05$ & $79.86 \pm 0.03$ & $21.25 \pm 0.01$ & $85.46 \pm 0.01$ \\
\hline WS-6 & 0.7 & 146.00 & $56.13 \pm 2.26$ & $2.96 \pm 0.19$ & $2.03 \pm 0.13$ & $30.08 \pm 2.91$ & $20.60 \pm 1.99$ & $20.00 \pm 0.04$ & $86.30 \pm 0.03$ \\
\hline WS-7 & 1.4 & 146.00 & $63.26 \pm 1.58$ & $2.26 \pm 0.28$ & $1.55 \pm 0.19$ & $16.31 \pm 1.75$ & $11.17 \pm 1.20$ & $15.19 \pm 0.03$ & $89.59 \pm 0.02$ \\
\hline
\end{tabular}

a)Productive percentage represents the percent of compound accounted for the removed $\mathrm{NO}_{3}^{-}-\mathrm{N}$.

Data are presented as mean \pm S.D., based on three replicates.

\section{Nitrate Transformation by the Isolates under Aerobic Conditions}

The efficiency of aerobic denitrification was evaluated by four strains with nitrate as the sole nitrogen source (Table 2). The results showed that all four strains could utilize nitrate. The three Pseudomonas sp. strains (WS-1, WS-6, and WS-7) removed 54.49 61.69\% and $83.68 \sim 87.42 \%$ of total nitrogen and nitrate, respectively, which was much more than that of WS-4. All four strains accumulated $\mathrm{NO}_{2}^{-}-\mathrm{N}$ on the similar level of 2.97 4.02 $\mathrm{mg} / \mathrm{L}$. The three Pseudomonas sp. strains produced a small amount of $\mathrm{NH}_{4}^{+}-\mathrm{N}$, ranging from 1.18 to $3.73 \mathrm{mg} / \mathrm{L}$ (except Agrobacterium sp. WS-4).

\section{Nitrite Transformation by the Isolates under Aerobic Conditions}

Aerobic denitrification efficiency by four strains with nitrite as the sole nitrogen source was evaluated (Table 3 ). The results showed that all four strains could utilize nitrite. Three Pseudomonas sp. strains (WS-1, WS-6, and WS-7) removed $56.13 \sim 63.26 \%$ of total nitrogen, which was much more than that of WS-4 (4.03\%). All four strains consumed approximately similar amounts of $\mathrm{NO}_{2}^{-}-\mathrm{N}(86.49 \sim 89.59 \%)$. The strain WS-4 produced maximal amount of $\mathrm{NO}_{3}^{-}-\mathrm{N}$ $(116.60 \mathrm{mg} / \mathrm{L})$, which was greater than that of the other strains $(16.31 \sim 30.08 \mathrm{mg} / \mathrm{L})$. The three Pseudomonas sp. strains produced a small amount of $\mathrm{NH}_{4}^{+}-\mathrm{N}$, ranging from 2.26 to $4.73 \mathrm{mg} / \mathrm{L}$ (except Agrobacterium sp. WS-4).

\section{Discussion}

Traditionally, heterotrophic nitrifying strains were usually obtained from wastewater $[2,10]$ or membrane bioreactors [3, 7]. In our works, various environment samples, such as soil, sludge, and water, were screened for microorganisms with heterotrophic nitrification ability. As a result, four strains were finally isolated from three different environments. This indicates that heterotrophic nitrifying bacteria were rich in water, soil, and sludge environments.
The four newly isolated strains belonged to two genus, namely Pseudomonas sp. and Agrobacterium sp. (Fig. 1). Pseudomonas sp. was a very common genus with the ability of heterotrophic nitrification $[2,10]$. The genus could be classified into three groups based on their modes of denitrification [6]. The first group reduces nitrate to nitrogen gas directly without accumulating nitrite. The second group possesses a two-phase denitrification process, and the remaining isolates accumulate nitrite at low concentration, just like the four strain we isolated (Table 1). Similarly, another Pseudomonas sp. strain was isolated from piggery wastewaters treatment system which removed $35 \mathrm{mg} / \mathrm{L} \mathrm{NH}_{4}^{+}-\mathrm{N}$ with few $\mathrm{NO}_{2}^{-}-\mathrm{N}$ accumulation [10].

Heterotrophic nitrification by Agrobacterium sp. was not reported until 2011 with a strain was isolated from landfill leachate treatment system. The strain could remove about $65 \mathrm{mg} / \mathrm{L} \mathrm{NH}_{4}^{+}-\mathrm{N}$ within $12 \mathrm{~h}$ and without nitrite and nitrate accumulation [11]. In our work, the newly isolated Agrobacterium sp. WS-4 removed 94.28\% of $\mathrm{NH}_{4}^{+}-\mathrm{N}(146 \mathrm{mg} / \mathrm{L})$ and only $1.30 \%$ and $0.005 \%$ of it was transformed to $\mathrm{NO}_{3}^{-}-\mathrm{N}$ and $\mathrm{NO}_{2}^{-}-\mathrm{N}$ respectively, indicating the potential of the strain in nitrogen removal. However, Agrobacterium sp. was usually described as aerobic microorganisms that could inhabit plant tissues causing tumors [12]. Therefore, most of strains in the genus are plant pathogens, implying the limitation of their application.

The nitrogen removal profiles were found to be relative to the type of genus. When ammonia was the sole nitrogen source, Agrobacterium sp. WS-4 accumulated less nitrate than three Pseudomonas sp. strains. When nitrate was the sole nitrogen source, the three Pseudomonas sp. strains removed much more nitrate than that of the remaining Agrobacterium sp. WS-4. Additionally, Agrobacterium sp. WS-4 did not produce ammonia while Pseudomonas sp. strains generated a small amount of ammonia (Table 2). To our knowledge, transformation of nitrate to ammonium was firstly reported in the liquid medium; however, the similar phenomena were observed in the soil [13]. Though nitrite removal percentage was approximately similar $(85.46 \sim 89.59 \%)$ with nitrite as the nitrogen source for the 
four strains (Table 3), the total nitrogen removal percentage of Agrobacterium sp. WS-4 was only $4.03 \%$, which was much less than that of Pseudomonas sp. strains (56.13 63.26\%). No ammonia was detected in the Agrobacterium sp. WS-4 culture while a small amount was in three Pseudomonas sp. strains'. Agrobacterium sp. WS-4 produced the maximal nitrate compared to levels generated by Pseudomonas sp. strains. These results suggested that it was a further nitrifying reaction, but not an aerobic denitrification for strain Agrobacterium sp. WS-4, when nitrite was employed as substrate.

\section{Conclusions}

All the four newly isolated strains could grow with ammonia, nitrate, and nitrite as the sole nitrogen source. The results demonstrated that not only water and sludge, but also soil, contained plenty of heterotrophic nitrifying microorganisms and they could all be applied in screening new strains. Based on the 16S rRNA sequences analysis, the strains WS-1, WS-6, and WS-7 were identified as Pseudomonas sp. and strain WS-4 was identified as Agrobacterium sp. The latter was an unfamiliar genus with heterotrophic nitrification ability. Nitrogen transformation profiles seemed to be related to the genus. Agrobacterium sp. WS-4 accumulated less nitrate than Pseudomonas sp. strains with ammonia as the nitrogen source. When nitrate or nitrite was the nitrogen source, Agrobacterium sp. WS-4 did not produce ammonia, and consumed the least nitrogen comparing to Pseudomonas sp. strains. Our study implied Pseudomonas sp. bacteria showed strong potential in treatment of high nitrogen wastewater.

\section{Acknowledgements}

The work was financial supported by Zhejiang Provincial Natural Science Foundation of China (Y5110147).

\section{References}

1. KULIKOWSKA D., JOZWIAK T., KOWAL P., CIESIELSKI S. Municipal landfill leachate nitrification in RBC biofilm-Process efficiency and molecular analysis of microbial structure. Bioresource Technol. 101, 3400, 2010.

2. ZHANG Q.L., LIU Y., AI G.M., MIAO L.L., ZHENG H.Y., LIU, Z.P. The characteristics of a novel heterotrophic nitrification-aerobic denitrification bacterium, Bacillus methylotrophicus strain L7. Bioresource Technol. 108, 35, 2012.

3. ZHAO B., HE Y.L., HUGHES J., ZHANG X.F. Heterotrophic nitrogen removal by a newly isolated Acinetobacter calcoaceticus HNR. Bioresource Technol. 101, 5194, 2010.

4. VERSTRAE W., ALEXANDE M. Heterotrophic nitrification by Arthrobacter sp. J. Bacteriol. 110, 955, 1972.

5. KHARDENAVIS A.A., KAPLEY A., PUROHIT H.J. Simultaneous nitrification and denitrification by diverse Diaphorobacter sp. Appl. Microbiol. Biot. 77, 403, 2007.

6. ZHANG J.B., WU P.X., HAO B., YU Z.N. Heterotrophic nitrification and aerobic denitrification by the bacterium Pseudomonas stutzeri YZN-001. Bioresource Technol. 102, 9866, 2011.

7. ZHENG H.Y., LIU Y., AGO X.Y., AI G.M., MIAO L.L., LIU Z.P. Characterization of a marine origin aerobic nitrifying-denitrifying bacterium. J. Biosci. Bioeng. 114, 33, 2012.

8. LIU F.F., ZHOU D.P., WU S.H., ZHANG M., CHU C.B., FAN J.Q., JIANG Z.F. Isolation and identification of heterotrophic nitrifiers from cultivation wastewater. Jounal of Agro-environment Science. 29, 2232, 2010.

9. FREAR D.S., BURRELL R.C. Spectrophotometric method for determining hydroxylamine reductase activity in higher plants. Anal. Chem. 27, 1664, 1995.

10. SU J.J., YEH K.S., TSENG P.W. A strain of Pseudomonas $\mathrm{sp}$. isolated from piggery wastewater treatment systems with heterotrophic nitrification capability in Taiwan. Curr. Microbiol. 53, 77, 2006.

11. CHEN Q., NI J.R. Heterotrophic nitrification-aerobic denitrification by novel isolated bacteria. J. Ind. Microbiol. Biot. 38, 1305, 2011.

12. GEORGIEV M.I., AGOSTINI E., LUDWIG-MULLER J., XU J.F. Genetically transformed roots: from plant disease to biotechnological resource. Trends Biotechnol. 30, 528, 2012.

13. BAGGS E.M. A review of stable isotope techniques for $\mathrm{N}_{2} \mathrm{O}$ source partitioning in soils: recent progress, remaining challenges and future considerations. Rapid Commun. Mass Sp. 22, 1664, 2008. 